\title{
Jakość życia pacjentów ze schizofrenią
}

\author{
Quality of life of patients with schizophrenia
}

\section{AGNIESZKA OKROJ ${ }^{1}$}

1 Szpital Lipno Sp. Z o.o.

http://dx.doi.org/10.21784/IwP.2021.008

\section{Streszczenie}

Wstęp. Schizofrenia jest chorobą psychiczną, którą charakteryzuje zróżnicowany obraz i przebieg kliniczny, charakteryzuje się przede wszystkim zakłóceniami myślenia i postrzegania, a także niedostosowanym i spłyconym afektem. Etiopatogeneza nie jest do końca znana, jedną z uznawanych teorii jest udział czynników biopsychospołecznych, w tym stresu. Wiek zachorowania przypada zazwyczaj na okres wczesnej dorosłości - u kobiet jest to 25-34 rok życia, a u mężczyzn 15-24 rok życia.

Cel. Celem badań była ocena jakości życia w kontekście domen życia pacjentów ze schizofrenią.

Materiały i metody. Badaniem objęto grupę 100 pacjentów leczonych w Szpital Lipno Sp. z o.o., u których zdiagnozowano schizofrenię. Wiek badanych mieścił się w zakresie 18-75 lat. Narzędziem badawczym był kwestionariusz SQLS-R4 (Schizophrenia Quality of Life Scale Revision 4) poszerzony o autorską metryczkę.

Wyniki. Respondenci dokonując subiektywnej oceny jakości życia określili jako stan zadawalający.

Jakość życia w sferze witalnej była na wyższym poziomie niż w domenie psychospołecznej oraz ogólnym zadowoleniu.

Wnioski. Schizofrenia to schorzenia, które w istotny sposób przyczynia się do obniżenia poziomu jakości życia głównie w domenie psychospołecznej.

Słowa kluczowe: schizofrenia, jakość życia 


\section{Summary}

Introduction. Schizophrenia is a mental illness characterized by a varied picture and clinical course, characterized primarily by disturbances in thinking and perception, as well as maladjusted and shallow affect. The etiopathogenesis is not fully known, one of the accepted theories is the involvement of biopsychosocial factors, including stress. The age of onset usually falls in early adulthood - for women it is 25-34 years of age, and for men 15-24 years of age. The aim. The aim of the research was to assess the quality of life in the context of the life domains of patients with schizophrenia.

Materials and methods. The study included a group of 100 patients treated at Szpital Lipno Sp. z o.o. who have been diagnosed with schizophrenia. The age of the respondents ranged from 18-75 years. The research tool was the SQLS-R4 questionnaire (Schizophrenia Quality of Life Scale Revision 4) extended with an original certificate.

Results. The respondents, making a subjective assessment of the quality of life, described it as satisfactory.

The quality of life in the vital sphere was higher than in the psychosocial domain and in general satisfaction

Conclusions. Schizophrenia is a disease that significantly contributes to the reduction of the quality of life, mainly in the psychosocial domain.

Keywords: schizophrenia, quality of life

\section{Wstęp}

Schizofrenia spośród chorób i zaburzeń psychicznych stanowi jeden z podstawowych problemów psychiatrii klinicznej [1]. Uznawana jest za chorobę najcięższą i najczęstszą z chorób psychicznych [2]. Światowa Organizacja Zdrowia (WHO) przedstawia dane donoszące, iż ponad 21 milionów ludzi na całym świecie zmaga się ze schizofrenią [3]. W Polsce liczba pacjentów ze schizofrenią szacowana jest na ok. 400 tys. [4]. Roczna zapadalność na schizofrenię w świecie wynosi od 15 do 30 przypadków na 100 tys. osób, a rozpowszechnienie od 2,7 do 8,3 przypadków na 1 tys. osób [5]. Wiek zachorowania przypada zazwyczaj na okres wczesnej dorosłości - u kobiet jest to 25-34 rok życia, a u męż- 
czyzn 15-24 rok życia. U kobiet mówi się również o dwóch szczytach zachorowań - jednym około 20 rok życia i kolejnym po 35 roku życia. W sumie do 20 roku życia pierwszych objawów choroby doświadcza od 20 do 40\% chorych [5, 6]. Względnie dużo zachorowań, bo około 15\%, pojawia się po 45 roku życia [5, 6]. Wcześniejszy początek choroby wiąże się z gorszą prognozą dla chorego [4]. Schizofrenia charakteryzuje się przede wszystkim zakłóceniami myślenia i postrzegania, a także niedostosowanym i spłyconym afektem. Choroba ta jest schorzeniem przewlekłym. Znaczna część osób z tym zaburzeniem w ciągu całego swojego życia (od momentu diagnozy) doświadcz różnych objawów wytwórczych oraz narastania negatywnych symptomów, powtarzających się okresów zaostrzeń i remisji.

Chorzy mają trudności nie tylko, np. z prawidłowym funkcjonowaniem rodzinnym, wywiązywaniem się z ról społecznych, ogólnym budowaniem relacji z innymi osobami, ale także ze zdobyciem lepszego wykształcenia, a tym samym utrzymaniem płynności finansowej, a także poprawą warunków bytowania. Należy zaznaczyć, że część chorych na schizofrenię doświadcza problemów z podstawowymi, fundamentalnymi aktywnościami życiowymi. Pacjenci często nie potrafią sami zmienić sytuacji, w której się znajdują. Czują się zagubieni, bezradni. W konsekwencji poziom jakości ich życia jest często niedostateczny, oceniany negatywnie.

\section{Cel}

Celem niniejszej pracy badawczej była ocena jakości życia pacjentów chorujących na schizofrenię w odniesieniu do domeny fizycznej, psychologicznej i społecznej.

\section{Materiał i metody}

Badania przeprowadzono z wykorzystaniem sondażu diagnostycznego i szacowania. Skorzystano przy tym z techniki ankietowania 
i pomiaru. Okres badań obejmował od października do grudnia $2020 \mathrm{r}$. badania odbyły się na terenie Szpitala Lipno Sp. z o.o. przy ul. Nieszawskiej 6. w trakcie hospitalizacji.

Narzędziem badawczym był kwestionariusz SQLS-R4 (Schizophrenia Quality of Life Scale Revision 4) poszerzony o autorską metryczkę. Skala SQLS-R4 opracowana została przez Wilkinsona i wsp. do pomiaru jakości życia osób ze zdiagnozowaną schizofrenią [6]. Udział w badaniu miał charakter anonimowy i dobrowolny. Przed przystąpieniem do badań uzyskano pisemną zgodę Komisji Bioetycznej nr INoZ.005.01.2021 oraz zgodę Dyrektora Szpital Lipno Sp. z o.o. nr DP.15/10/2021.

Badania przeprowadzono wśród 100 pacjentów chorych na schizofrenię z oddziałów psychiatrycznych w Lipnie. W badaniach zastosowano celowy dobór próby, a wśród osób ankietowanych znalazły się tylko i wyłącznie osoby z rozpoznaną schizofrenią w trakcie hospitalizacji. Kryteria włączenia pacjentów do badania to: wiek $\geq 18$ lat, wyrażenie zgody na udział w badaniu. Do opracowania wyników badań zastosowano rozkład liczbowy, miary tendencji centralnej (średnią arytmetyczną), miary zmienności (odchylenie standardowe, procenty, korelacje), miary rzetelności oraz testy istotności statystycznej. Celem badania różnic międzygrupowych wykorzystano test t dla prób niezależnych i zależnych oraz jednoczynnikową ANOVE w zależności od rodzaju analizowanych danych. Ponadto do analizy zależności między zmiennymi ilościowymi wykorzystano korelację r-Pearsona. Obliczenia statystyczne wykonano w programie PASW Statistic 18. przyjęto poziom statystyczności p<0,05.

\section{Wyniki}

Większość respondentów stanowiły kobiety $(\mathrm{n}=60)$. Badani były w zróżnicowanym wieku. Najczęściej był to wiek między 26 a 35 rokiem życia $(26,0 \% ; n=26)$ oraz między 18 a 25 i 45 a 55 rokiem życia (po 23,0\%; n=23). Ponadto 16,0\% pacjentów było między 36 a 45 rokiem życia (n=16), a 12,0\% między 56 a 75 rokiem życia ( $n=12)$. Miejsce zamieszkania to mieszkańcy wsi $(n=50)$, a w drugiej połowie miasta 
$(\mathrm{n}=50)$. Wykształcenie badanych pacjentów ze schizofrenią było zróżnicowane, najczęściej legitymowali się oni wykształceniem średnim $36,0 \%(n=36)$ i zawodowym - 28,0\% (n=28). Osoby z wykształceniem wyższym stanowiły $15,0 \%$ badanych ( $\mathrm{n}=15)$, a z gimnazjalnym $13,0 \%$ $(\mathrm{n}=13)$. Najniższy odsetek osób to pacjenci z wykształceniem podstawowym stanowiący $8,0 \%$ badanej próby $(n=8)$. Pacjenci ze schizofrenią w większości przypadków mieszkali z rodziną - 78,0\% (n=78), a w pozostałych 22,0\% przypadkach mieszkali samotnie $(n=22)$.

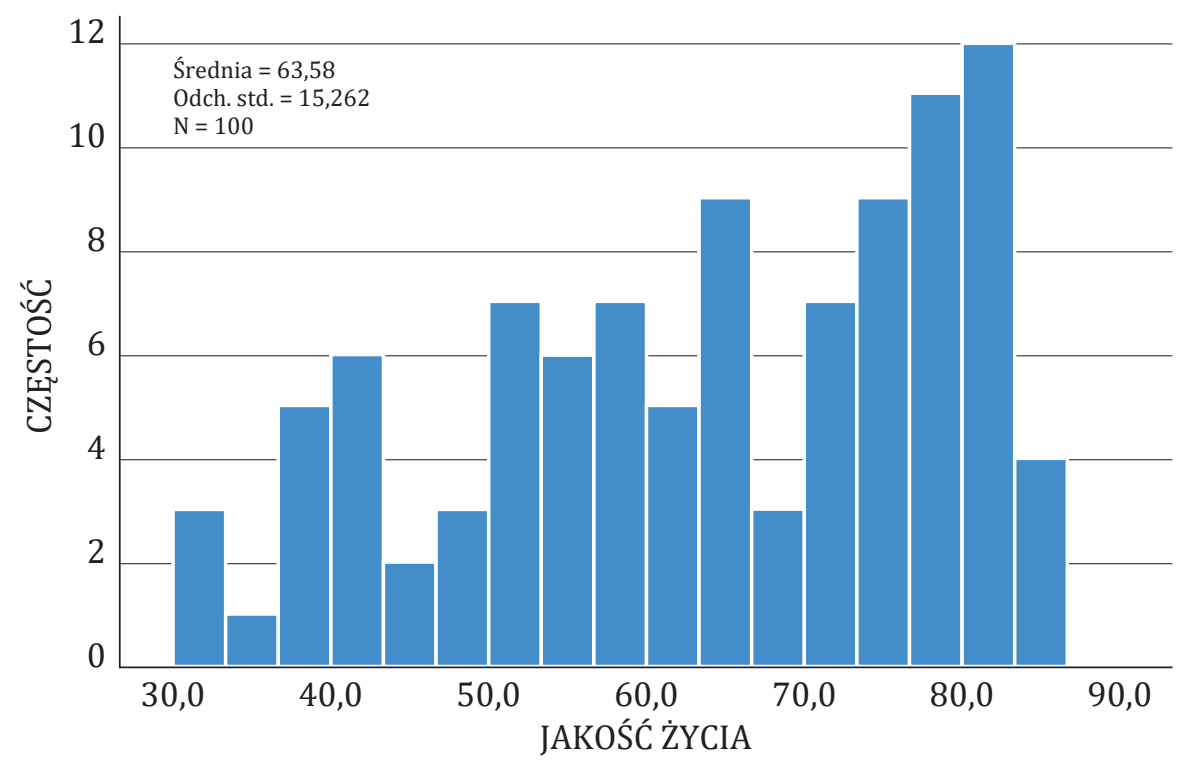

Ryc. 1. Jakość życia badanych pacjentów

W badanej grupie pacjentów jakość życia wynosiła średnio 63,58\% przy odchyleniu standardowym $\mathrm{SD}=15,262 \%$, a wyniki wahały się od 31,1 do $85,6 \%$. W domenie psychospołecznej wyniki wynosiły od 27,5 do $91,3 \%$, wynosząc średnio $M=65,37 \%$; zaś w skali witalności od 25,0 do $82,7 \%$, wynosząc średnio $M=60,96 \%$. $Z$ danych tych wynika, że pacjenci lepiej oceniali jakość życia w sferze witalnej niż w domenie psychospołecznej. Witalność była także wyżej oceniana niż ogólna jakość 
życia pacjentów. Płeć badanych chorych na schizofrenię a ocena jakości życia i ich domen nie wykazały statystycznej zależności (domeny psychospołecznej i witalności) ( $p>0,05)$. Wyniki testu jednoczynnikowej ANOVA potwierdziły, że istnieje istotna różnica w ocenie jakości życia

Tabela 1. Wiek pacjentów ze schizofrenią a poziom jakości życia w poszczególnych domenach.

\begin{tabular}{|c|c|c|c|c|c|c|}
\hline & & $\mathrm{N}$ & M & SD & $\begin{array}{l}\text { Błąd stan- } \\
\text { dardowy }\end{array}$ & $\begin{array}{c}\text { Jedno- } \\
\text { czynniko- } \\
\text { wa ANOVA }\end{array}$ \\
\hline \multirow{7}{*}{ 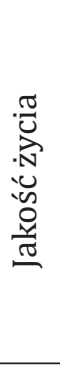 } & 18-25 lat & 23 & 62,439 & 16,6182 & 3,4651 & \multirow{7}{*}{$\begin{array}{l}F=2,149 \\
p=0,066\end{array}$} \\
\hline & 26-35 lat & 26 & 62,377 & 15,9223 & 3,1226 & \\
\hline & $36-45$ lat & 16 & 69,319 & 11,0289 & 2,7572 & \\
\hline & 46-55 lat & 23 & 62,187 & 13,1368 & 2,7392 & \\
\hline & 56-65 lat & 6 & 75,383 & 5,7666 & 2,3542 & \\
\hline & $66-75$ lat & 6 & 51,400 & 22,3356 & 9,1185 & \\
\hline & Ogółem & 100 & 63,580 & 15,2622 & 1,5262 & \\
\hline \multirow{7}{*}{ 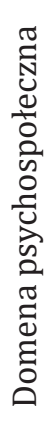 } & 18-25 lat & 23 & 65,296 & 18,8098 & 3,9221 & \multirow{7}{*}{$\begin{array}{l}F=1,876 \\
p=0,106\end{array}$} \\
\hline & 26-35 lat & 26 & 63,919 & 18,8070 & 3,6884 & \\
\hline & 36-45 lat & 16 & 72,369 & 12,4258 & 3,1064 & \\
\hline & 46-55 lat & 23 & 62,574 & 16,1373 & 3,3649 & \\
\hline & 56-65 lat & 6 & 76,883 & 7,1401 & 2,9150 & \\
\hline & $66-75$ lat & 6 & 52,500 & 25,3476 & 10,3481 & \\
\hline & Ogółem & 100 & 65,371 & 17,6802 & 1,7680 & \\
\hline \multirow{7}{*}{ 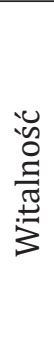 } & 18-25 lat & 23 & 58,117 & 14,5252 & 3,0287 & \multirow{7}{*}{$\begin{array}{l}F=2,498 \\
p=0,038\end{array}$} \\
\hline & 26-35 lat & 26 & 60,054 & 13,3827 & 2,6246 & \\
\hline & $36-45$ lat & 16 & 64,656 & 10,9515 & 2,7379 & \\
\hline & 46-55 lat & 23 & 61,622 & 10,9515 & 2,2835 & \\
\hline & 56-65 lat & 6 & 73,083 & 4,5301 & 1,8494 & \\
\hline & $66-75$ lat & 6 & 49,683 & 20,0279 & 8,1764 & \\
\hline & Ogółem & 100 & 60,865 & 13,3880 & 1,3388 & \\
\hline
\end{tabular}


w domenie witalność a wiekiem respondentów chorych na schizofrenię ( $\mathrm{p}=0,038 ; \mathrm{n}=100)$. Natomiast brak jest różnic w ocenie ogólnej jakości życia w odniesieniu do płci badanych. $Z$ danych średnich wynika, że najniżej jakość życia w domenie witalność oceniały osoby w wieku od 56 do 65 lat $(M=73,08 ; n=6)$ oraz pacjenci między 36 a 45 rokiem życia $(M=64,66$; $\mathrm{n}=16)$, a najlepiej domenę tę oceniały osoby najstarsze, tj. między 66 a 75 rokiem życia $(M=49,68 ; n=6)$ i najmłodsze w wieku od 18 do 25 lat $(M=58,12 ; n=23)$. Wyniki testu $t$ dla prób niezależnych wykazały istotne różnice w ocenie jakości życia a sposób zamieszkania pacjentów ze schizofrenią w przypadku oceny ogólnej jakości życia $(\mathrm{p}=0,040 ; \mathrm{n}=100)$ i oceny domeny psychospołecznej $(\mathrm{p}=0,034 ; \mathrm{n}=100)$. Uzyskane wyniki wskazują, że ogólna ocena jakości życia była lepsza wśród pacjentów ze schizofrenią mieszkających z rodziną ( $M=61,92 ; n=78)$ od osób zamieszkujących samotnie $(M=69,46 ; n=22)$.

\section{Dyskusja}

Schizofrenia to poważne zaburzenie psychiczne charakteryzujące się utratą kontaktu z rzeczywistością, psychozą, halucynacjami, urojeniami, nieprawidłowym myśleniem, irracjonalnym myśleniem, dziwacznym zachowaniem, ograniczonym zakresem emocji, osłabieniem motywacji i upośledzeniem funkcji społecznych i zawodowych, przewlekłą chorobą psychiczną, która w różny sposób wpływa na zachowanie, myśl i emocje [7].

W dzisiejszych czasach głównym celem opieki psychiatrycznej nie jest skupianie się tylko na zmniejszaniu (tych) objawów psychopatologicznych, ale (jedną z części głównego celu opieki psychiatrycznej jest) poprawa jakości życia pacjenta. Obniżona jakość życia jest często ważną przyczyną lub następstwem chorób psychicznych i należy ją uwzględnić w kompleksowym planie leczenia. Badania literaturowe wskazują, że chorzy psychicznie deklarują niższą ogólną jakość życia w porównaniu z populacją ogólną [8].

Osoby ze schizofrenią są bardziej narażone na liczne i chroniczne deficyty społeczne, poznawcze i behawioralne, które mogą prowadzić do nieodpowiednich praktyk zdrowotnych i samoopieki [9]. 
Udowodniono również, że jakość życia chorych na schizofrenię zależy od różnych uwarunkowań, w tym czynników socjodemograficznych, klinicznych, ekonomicznych czy społecznych. Równocześnie pojawiło się wiele wątpliwości co do rzetelności subiektywnej oceny jakości życia ocenianej przez pacjentów, zwłaszcza ze względu na brak wglądu i obecność objawów psychopatologicznych [10]

Jednak Voruganti i in. udowodnili, że chorzy na schizofrenię w okresie remisii i chętni do współpracy są w stanie odpowiednio ocenić jakość swojego życia [11]. Kwestia różnic w ocenie jakości życia mężczyzn i kobiet była szeroko dyskutowana w piśmiennictwie, chociaż zaobserwowano wiele sprzeczności. Wiele badań wykazało, że mężczyźni mieli gorszą jakość życia niż kobiety, zwłaszcza w zakresie funkcjonowania społecznego [12] co potwierdzają uzyskane wyniki badań własnych. Jarema i in. udowodnili, że jakość życia mężczyzn ze schizofrenią była lepsza niż u kobiet [13]. W niektórych przypadkach, podobnie, jak w badaniach własnych nie stwierdzono istotnego związku między płcią a jakością życia [14]. Podobnie w badaniach Makara-Studzińska, Wołyniak i Partyka [15], gdzie ogólną jakość życia lepiej oceniały kobiety niż mężczyźni. Nie było jednak różnic istotnych statystycznie między mężczyznami i kobietami w poszczególnych dziedzinach oraz w ogólnym postrzeganiu zdrowia oraz badaniach Badury-Brzozy i wsp. [16], Chądzińskiej i wsp. [17]. Najniżej jakość życia oceniały osoby od 55 do 65 roku życia, a najlepiej najstarsi między 66 a 75 rokiem życia. Inne wyniki uzyskali Klamka, Mazurowski, Gezela i wsp., gdzie młodsi pacjenci oceniali swoją jakość życia gorzej w sferze funkcjonowania psychospołecznego [18]. W badaniach własnych wyniki korelacji r-Pearsona nie wykazały istotnych zależności między wiekiem pacjentów oceną jakości życia i jej domen. Brak zależności między wiekiem a jakością życia ukazują także inne badania, w tym analiza dokonana przez Badurę-Brzozę i wsp. [16]. Wykształcenie badanych nie różnicowało poczucia jakości życia i jej domen. Powyższe potwierdza brak istotnych zależności między wykształceniem a jakością życia i jej domenami. Brak zależności między wykształceniem a jakością życia ukazują także inne badania, w tym analiza dokonana przez Badu- 
rę-Brzozę i wsp. [16]. W badaniach wykazano zaś dodatnią zależność między oceną jakości życia a wykształceniem [19]. Sposób zamieszkania różnicuje ocenę jakości życia i jej domen wśród osób ze schizofrenią nie została w całości potwierdzona. Wykazano istotne różnice w ocenie jakości życia domenie psychospołecznej a sposobem zamieszkania pacjentów ze schizofrenią. W obu przypadkach wyższą ocenę jakości życia i ocenę domeny psychospołecznej wykazywali pacjenci mieszkający z rodziną niż samotnie. Powszechnie wiadomo, że wsparcie społeczne uważane jest za jeden z najważniejszych czynników ochronnych zdrowia psychicznego, a także wiąże się z lepszą jakością życia osób ze schizofrenią [20]. Potwierdzają to także rozważania Cechnickiego, Wojciechowskiej i Valdez na temat sieci społecznej osób chorych na schizofrenię [21]. Analizując związki pomiędzy wskaźnikami sieci społecznej a wskaźnikami jakości życia autorzy wykazali, że istotne okazały się zakres sieci społecznej oraz obecność oparcia społecznego. Większy zakres sieci oraz wyższy poziom oparcia społecznego wykazuje pozytywny związek z lepszym ogólnym, subiektywnym zadowoleniem z jakości życia. Wyniki te potwierdzają inne badania [22], mówiących o tym, że pacjenci z większą i bardziej satysfakcjonującą siecią oparcia mają lepszą jakość życia lub, z innej strony, że mały zakres sieci społecznej, mała liczba kontaktów interpersonalnych są związane z gorszymi subiektywnymi wskaźnikami jakości życia.

\section{Wnioski}

1. Płeć badanych chorych na schizofrenię nie wykazała istotnej różnicy w ocenie poziomu jakości życia i ich domen (domeny psychospołecznej i witalności).

2. Istnieje istotna różnica w ocenie jakości życia w domenie witalność a wiek. Najniżej oceniły ją osoby w wieku 56-65 lat oraz między 36-45 rokiem życia, a najlepiej osoby najstarsze miedzy 66-75 rokiem życia i najmłodsze w wieku 18-25 lat. Brak jest natomiast istotnych różnic w ocenie domeny psychospołecznej ze względu na wiek. 
3. W badanej grupie respondentów nie ma różnic w ocenie jakości życia i jej domen a miejscem zamieszkania oraz wykształceniem pacjentów ze schizofrenią.

4. Ankietowani odczuwają istotną różnicę w ocenie jakości życia ze względu na sposób zamieszkania, osoby zamieszkujące z rodziną wykazują poczucie bezpieczeństwa , a co za tym idzie wyższy poziom jakości życia.

\section{Zalecenia dla praktyki pielęgniarskiej.}

Jakość życia osób chorujących na schizofrenię ma istotny wpływ na funkcjonowanie w życiu codziennym. Działania na rzecz poprawy jakości życia pacjentów ze schizofrenią zmierzają do zapewnienia choremu wsparcia i poczucia bezpieczeństwa. Pielęgniarka w relacjach z pacjentem i jego rodziną powinna wykazywać empatię, wrażliwość i cierpliwość. Tylko holistyczne postrzeganie problemów chorego stanowi gwarancję poprawy stanu zdrowia pacjenta, a tym samym optymalizuje jakość jego życia.

\section{Bibliografia:}

1. Wilczek-Różyczka E. Podstawy pielęgniarstwa psychiatrycznego. Wydawnictwo Lekarskie PZWL. Warszawa 2019:152.

2. Jerema M., Rabe-Jagłońska J. Psychiatria. Podręcznik dla studentów medycyny. Wydawnictwo Lekarskie PZWL. Warszawa 2011:123-129.

3. Sieradzki A. Schizofrenia i jej konsekwencje zdrowotne jako problem zdrowia psychicznego. Piel Zdr Publ 2019,9:310.

4. Araszkiewicz A. i inni. Biała Księga - osoby chorujące na schizofrenię w Polsce. Instytut Praw Pacjenta i Edukacji Zdrowotnej 2011:8.

5. Szulc A., Samochowicz J. Schizofrenia z objawami negatywnymi. Wydawnictwo Lekarskie PZWL. Warszawa 2019:11-12,20-21.

6. Wilkinson G., Hesdon B., Wild D. i wsp. Samodzielna miara jakości życia osób ze schizofrenią: SQLS. Br J Psychiatry 2000,177:42-46. 
7. Eack S. M., Newhill C. E. Psychiatric Symptoms an Quality of Life in Schizophrenia:A Meta-Analysis. Schizophrenia Bulletin. 2007;33(5):1225-1237.

8. Alshowkan A., Curtis J., White Y. Quality of life for people with schizophrenia a literature review. The Arab J of Psychiatry. 2003;23(2):122-131.

9. Bonicatto S. C., Dew M. A., Zaratiegui R. i wsp. Adult outpatients with depression:worse quality of life than in other chronic medical the diseases in Argentina. Soc Sci Med. 2001;52:911-919.

10. Chan S, Yu IW. Quality of life of clients with schizophrenia. Issues and Innovations in nursing practice. J Adv Nurs 2004;45(1):72-831.

11. Voruganti L, Heslegrave R, Awad AG, Seeman MV. Quality of life measurement in schizophrenia: reconciling the quest for subjectivity with the question of reliability. Psychol Med 1998;28:165-172.

12. Caron J, Lecomte Y, Stip E, Renaud S. Predictors of quality of life in schizophrenia. Commun Ment Health J 2005;41(4):399-417.

13. Jarema M: Th e study of quality of life as an alternative form of evaluation. New Med 1996;3:15-16.

14. Dimitriou P, Anthony D, Dyson S. Quality of life for patients with schizophrenia living in the community in Greece. J Psychiatr Ment Health Nurs 2009;16:546-552.

15. Gałecki P., Szulc A. Psychiatria. Capyright by Edra Urban \& Partner. Wrocław 2018;161-163.

16. Badura - Brzoza K., Piegza M., Błachut M. i inni. Ocena wpływu wybranych czynników psychicznych i socjodemograficznych na jakość życia pacjentów ze schizofrenią. Psychiatria Polska. 2012;XLVI(6):975-984

17. Chądzyńska M, Kasperek B, Meder J, Spiridonow K. Jakość życia osób przewlekle chorych na schizofrenię w ocenie ich samych i ich rodzin. Psychiatr. Pol. 2002;5:703-715.

18. Klamka A., Mazurowski K., Gezela M. i wsp. Czynniki związane z jakością życia pacjentów ze schizofrenią - badanie przy zastosowaniu skali AQLS. Nowiny Lekarskie. 2006;75(6):564-567. 
19. Konieczyńska Z, Jarema M, Cikowska G. Badanie jakości życia zależnej od stanu zdrowia chorych leczonych z powodu schizofrenii na oddziale dziennym. Psychiatr. Pol. 1997;31:323-332.

20. Bergson-Tops A, Hansson L. Quantitative and qualitative aspects of social network in schizophrenic patients living in the community. Relationship to sociodemographic characteristics and clinical factors and subjective quality of life. Int J Soc Psychiat 2001;47(3):67-77.

21. Cechnicki A., Wojciechowska A., Valdes M. Sieć społeczna a jakość życia osób chorujących na schizofrenię w siedem lat od pierwszej hospitalizacji. Psychiatria Polska. 2007;XLI(4):527-537.

22. Lehman AF. The effects of psychiatric symptoms on quality of life assessments among the chronic mentally ill. Evaluat. Progr. Plann. 1983;6:143155. 